\title{
Organic farmers use of wild food plants and fungi in a hilly area in Styria (Austria)
}

\author{
Christoph Schunko* and Christian R Vogl
}

\begin{abstract}
Background: Changing lifestyles have recently caused a severe reduction of the gathering of wild food plants. Knowledge about wild food plants and the local environment becomes lost when plants are no longer gathered. In Central Europe popular scientific publications have tried to counter this trend. However, detailed and systematic scientific investigations in distinct regions are needed to understand and preserve wild food uses. This study aims to contribute to these investigations.

Methods: Research was conducted in the hill country east of Graz, Styria, in Austria. Fifteen farmers, most using organic methods, were interviewed in two distinct field research periods between July and November 2008. Data gathering was realized through freelisting and subsequent semi-structured interviews. The culinary use value (CUV) was developed to quantify the culinary importance of plant species. Hierarchical cluster analysis was performed on gathering and use variables to identify culture-specific logical entities of plants. The study presented was conducted within the framework of the master's thesis about wild plant gathering of the first author. Solely data on gathered wild food species is presented here.

Results: Thirty-nine wild food plant and mushroom species were identified as being gathered, whereas 11 species were mentioned by at least 40 percent of the respondents. Fruits and mushrooms are listed frequently, while wild leafy vegetables are gathered rarely. Wild foods are mainly eaten boiled, fried or raw. Three main clusters of wild gathered food species were identified: leaves (used in salads and soups), mushrooms (used in diverse ways) and fruits (eaten raw, with milk (products) or as a jam).

Conclusions: Knowledge about gathering and use of some wild food species is common among farmers in the hill country east of Graz. However, most uses are known by few farmers only. The CUV facilitates the evaluation of the culinary importance of species and makes comparisons between regions and over time possible. The classification following gathering and use variables can be used to better understand how people classify the elements of their environment. The findings of this study add to discussions about food heritage, popularized by organizations like Slow Food, and bear significant potential for organic farmers.
\end{abstract}

\section{Background}

In Europe fast changing lifestyles and especially lack of time have recently caused a severe reduction of gathering wild plants and mushrooms [1,2], which in turn results in a loss of local knowledge about wild foods and about the local environment. This loss is serious for several reasons: gathering and use of wild plants and mushrooms is part

* Correspondence: christoph.schunko@boku.ac.at

1 Working Group: Knowledge Systems and Innovations, Division of Organic Farming, Department for Sustainable Agricultural Systems, University of Natural Resources and Applied Life Sciences (BOKU), Gregor-Mendel Straße 33, 1180 Vienna, Austria

Full list of author information is available at the end of the article of the cultural history of a region [3]; wild food species are part of people's local identity and traditions [4]; dishes made of wild foods are often identified as functional foods (foods with medicinal properties) [4,5]; and wild foods can contribute to overcoming periods of food shortage [4].

The above reasons make the preservation of local knowledge of gathering and use of wild food plants and mushrooms crucial. Several popular scientific publications, which aim to contribute to the preservation of wild food uses, have been released in German speaking countries (e.g. [6,7]). However, these publications often lack information about the origin, actuality, geographical dis- 
tribution or cultural significance of the identified uses and species. Since wild food knowledge is context specific, in the sense that very different wild food species are used in distinct regions and uses of one and the same species can differ widely from one region to another [8], this lack of information weighs heavily. Instead detailed and systematic scientific investigation is needed for understanding and preserving wild food uses in distinct regions. The aim of this research is to accomplish such detailed investigations. We aim to explore wild food uses of farmers in the hill country east of Graz, to identify the culinary most relevant species and to make out local classification schemes.

In Europe, scientific studies on wild foods have only recently increased and research has concentrated in the Mediterranean area, especially Spain (e.g. [2,9-11]), Italy (e.g. $[1,12,13])$, France and Greece [e.g. [8] for both] are countries in which multiple investigations were conducted.

In Central and Eastern Europe research on gathering and use of wild foods was rather limited recently. However, the difficult historic and political situation until the mid (Central Europe) or end (Eastern Europe) of the 20 th century allows us to assume that local knowledge about wild food plants has been and may still be prevalent in several areas [3]. Historic and recent sources for e.g. Poland [14], Hungary [15,16], Bosnia-Herzegovina [17], Slovenia [18] or Eastern Europe [19] acknowledge this.

For the research area at hand, no previous systematic studies on wild food uses could be elicited, although indications for plant and mushroom gathering were found: the anthropologist Gamerith, who did extensive research on styrian peasant food in the mid-20th century, wrote that "myriads of fruits and herbs gathered from nature and homegardens enriched the table" of peasants "and were snacked between the meals" [20]; an ethnographic article about peasant food in a valley in southwestern Styria mentions several wild gathered plant species used for salads (Taraxacum sp., Cichorium sp., Nasturtium sp., Hieracium sp., Crocus vernus) and for omelets (Urtica sp., Achillea sp., Glechoma hederacea) as well as fungi gathered for food (Boletus edulis, Clavaria aurea, Tricholoma gambosum, Tricholoma portentosum, Tricholoma terreum, Tricholoma equestre, Sparassis crispa, Polyporus squamosus, Clitopilus prunulus, Agaricus arvensis, Lactarius volemus, Russula virescens and other Russula sp.) [21]; the styrian dictionary "Steirischer Wortschatz", published in the year 1903, also lists wild foods and wild food uses [22]; and Ferk lists, in the year 1910, 189 styrian names for fungi and investigates the etymology of the herrenpilz (Boletus edulis), pfifferling (Cantharellus cibarius) and täubling (Russula sp.), obviously important mushrooms in the area [23]. Besides that, leaflets explaining and promoting the gathering of fruits, herbs, spices and fungi for own consumption and selling were published in the years 1916 [24] and 1942 [25]. These leaflets were released during the first and second world war, when food supplies were scarce, and the exploitation of all available food sources became necessary.

Moreover, research on wild gathered food species adds to the discussion about food heritage, popularized by organizations like Slow Food [26], since wild food uses are often traditional ones. Wild foods also have potential as innovative products in organic farming as, following the Council Regulation (EC) No 834/2007 on organic production, wild food species can be certified as organic.

\section{Methods}

Research was conducted in the hill country east of Graz, Styria, in Austria. The hill country is situated in the east of the provincial capital of Graz and covers an area of 215 $\mathrm{km}^{2}$. In total 29,000 people live there [27]. The annual precipitation averages 851 millimeters [28] and the average annual temperature is $9^{\circ} \mathrm{Celsius}$ [29]. The landscape is characterized by extended hills, divided into different sections by the Raab, Feistritz and Lafnitz rivers. Mixed deciduous forests prevail, dominated by Carpinus betulus, Quercus robur, Quercus petraea, Fagus sylvatica, Castanea sativa and Prunus avium subsp. avium [30].

The society of this region, before the Second World War, was marked by a highly agrarian population, with many people working on small units of land. After the war the expansion of agricultural production was the prime goal and in the subsequent decades agricultural production was increasingly rationalized and specialized [31]. Broiler poultry and pig production, in particular, experienced an important upturn and an increase in the production of corn accompanied this expansion. Furthermore, large scale fruit-growing became widely established [32].

Research was conducted between July and November 2008 and consisted of two distinct field research periods. In the first period, 15 farmers were interviewed. The addresses of the farmers were obtained by Snowball Sampling [33]. Seven organic farmers, whose addresses were randomly selected from a list of organic farmers in the area, presented the starting point. Farmers were selected as respondents since they are often knowledgeable in the customs of a region, work in food production and food preparation, work in and with nature and often live a more traditional lifestyle. Furthermore, organic farmers were selected in particular since the marketing of wild food products may represent a special marketing opportunity for them.

The sample comprised 12 organic and 3 conventional farmers, ten women and five men between the age of 34 and 61 (arithmetic mean: 49,8 years). All respondents, except one, were born and grew up in the research area. 
Nine respondents worked full-time on the farm whereas six respondents were part-time farmers. All respondents sold at least part of their products directly to final consumers.

In the first field research period freelisting, followed up by semi-structured interviews, was accomplished $[33,34]$. The freelisting question was: "Bitte zählen sie auf was in der Natur wächst und hier in der Umgebung gesammelt wird"; (literal translation: "Please list what grows in nature and is gathered in the neighborhood"). More detailed questions were then posed to investigate which parts of the plants are gathered and how the plants and mushrooms are used. In this paper, only the gathered wild plant and mushroom species used for food are presented.

In the second field research period, ten of these farmers were interviewed more thoroughly about the 22 most frequently listed plant and mushroom species (24 items since the flowers and the berries of Sambucus nigra and the flowers and the leaves of Taraxacum $s p$. are used in very distinctive ways and are therefore regarded as separate in the analysis) that were used as food. We determined if the plants and mushrooms were actually gathered in the years of 2007 or 2008, if they were gathered only from the wild or from cultivation, where they were gathered, at what distance from the farm and at which time(s) of the year.

Respondents' answers were written on prepared questionnaires during the interviews and entered into an $M S$ Access database [35] afterwards [36]. Additionally all interviews were recorded with a Philips Voicetracer 7890.

The freelist data and the gathering and use variables were analyzed by frequency and percentages. The use value (UV) of plants, first developed by Phillips and Gentry [37] and adjusted by Tardío and Pardo-de-Santayana [38], was adapted to the culinary use value (CUV) in this study. The UV "transforms the complex, multidimensional concept of 'importance' into standardized and comparable numerical scales and values" [39] and therefore expresses the cultural value of plant or mushroom species quantitatively. The calculation of the UV is based on the frequency and diversity of use. Hence, the UV of a species is high, when it is used by many respondents and in diverse ways, and the UV is low, when it is used by few respondents and only for few uses (study [37-39] for closer explanations). While the UV of a species is calculated through the frequency and diversity of uses in distinct use categories (e.g.: edible, medicine, construction,...), the CUV is calculated through the frequency and diversity of use in distinct categories of culinary preparation (boiled, fried, roasted/baked, raw, dried/condiment). Therefore the CUV is an index indicating the culinary importance of a species as considered in different preparation categories. Moreover, species were merged into groups according to gathered plant part or mushroom and CUVs were calculated for these general categories (as performed with food-categories before [40]).

The gather and use variables of the 24 most common wild gathered plants and mushrooms used as food were used in Hierarchical Cluster Analysis (HCA) applying Ward method [9]. HCA was conducted to identify culture-specific logical entities of plants and mushrooms and their usage profiles. For the HCA the characteristics of the 24 items were depicted through 31 binomial variables in a matrix $(1=$ true; $2=$ false $)$. The variables used were related to the frequency of listing, frequency of gathering, the gathered plant parts, dishes in which the species are used, location of gathering, distance of gathering from the farm and the time of the year when the species were gathered. For the frequencies of listing and the frequencies of gathering the percentage of respondents who listed or gathered a species was used $(<33 \%, 33-66 \%$, $>66 \%$ ). All other variables were considered as true, if at least two respondents listed a variable as true. HCA displays the similarities of the species or variables in dendrograms, where species or variables with similar parameter values are placed in common clusters. After the creation of the dendrograms we related the clusters of species to clusters of variables by comparing the clusters with the raw data. HCA was accomplished in SPSS 15.0 [41].

For convenience, in this paper fungi, although recognized as distinct, are sometimes listed together with plants.

The results of this study were returned to the informants via a letter including the internet address to download the final paper of the project.

\section{Results \\ Wild food plants}

The informants mentioned edible plants and mushrooms a total of 150 times (including double entries) referring to 39 different species (Table 1). Every informant listed between 0 and 19 wild food species (arithmetic mean: 10; standard deviation: 5.6).

The wild food species listed most frequently are chanterelle mushroom (Cantharellus cibarius), edible boletus mushroom (Boletus edulis), blackberry (Rubus subgenus Rubus spp.), parasol mushroom (Macrolepiota procera), wood strawberry (Fragaria vesca), flirt mushroom (Russula sp.), wild raspberry (Rubus idaeus), nettle (Urtica dioica), dandelion (Taraxacum sp.), blueberry (Vaccinium myrtillus) and sweet chestnut (Castanea sativa). These plant and mushroom species were listed by 80 to 40 percent of the respondents. Eleven other plants and mushrooms were listed by 13 to 33 percent of the respondents. Seventeen wild food species were listed only once.

The 39 species belong to 24 different plant and mushroom families. The family with the most species cited is 
Table 1: Aggregated freelist of wild food species gathered in the hill country east of $\mathrm{Graz}(\mathrm{n}=15)^{*}$

\begin{tabular}{|c|c|c|c|c|}
\hline Rank & Item & Frequency & Percentage & Average Rank \\
\hline 1 & Cantharellus cibarius & 12 & 80 & 5 \\
\hline 2 & Boletus edulis & 12 & 80 & 5,5 \\
\hline 3 & Rubus subgenus Rubus spp. & 11 & 73 & 4,727 \\
\hline 4 & Macrolepiota procera & 11 & 73 & 7 \\
\hline 5 & Taraxacum sp. & 10 & 67 & 6,8 \\
\hline 6 & Russula sp. & 9 & 60 & 7,333 \\
\hline 7 & Fragaria vesca & 9 & 60 & 5,444 \\
\hline 8 & Rubus idaeus & 8 & 53 & 5,375 \\
\hline 9 & Urticasp. & 8 & 53 & 5,625 \\
\hline 10 & Vaccinium myrtillus & 7 & 47 & 6,857 \\
\hline 11 & Castanea sativa & 6 & 40 & 9 \\
\hline 12 & Sambucus nigra & 5 & 33 & 3,2 \\
\hline 13 & Lactarius sect. Deliciosi & 4 & 27 & 10 \\
\hline 14 & Bellis perennis & 4 & 27 & 6,5 \\
\hline 15 & Juglans regia & 3 & 20 & 9 \\
\hline 16 & Rumex sp. & 2 & 13 & 4,5 \\
\hline 17 & Plantago lanceolata & 2 & 13 & 2,5 \\
\hline 18 & Amanita rubescens & 2 & 13 & 11 \\
\hline 19 & Allium ursinum & 2 & 13 & 10 \\
\hline 20 & Prunus avium subsp. avium & 2 & 13 & 12,5 \\
\hline 21 & Glechoma hederacea & 2 & 13 & 8,5 \\
\hline 22 & Thymus sp. & 2 & 13 & 8,5 \\
\hline 23 & Nasturtium sp. & 1 & 7 & 7 \\
\hline 24 & Galium odoratum & 1 & 7 & 7 \\
\hline 25 & Armoracia rusticana & 1 & 7 & 11 \\
\hline 26 & Achillea sp. & 1 & 7 & 1 \\
\hline 27 & Coprinus sp. & 1 & 7 & 14 \\
\hline 28 & Stellaria media & 1 & 7 & 14 \\
\hline 29 & Plantago major & 1 & 7 & 3 \\
\hline 30 & Ramaria botrytis & 1 & 7 & 17 \\
\hline 31 & Xerocomus badius & 1 & 7 & 18 \\
\hline 32 & Lepidium sp. & 1 & 7 & 19 \\
\hline 33 & Juniperus sp. & 1 & 7 & 9 \\
\hline 34 & Prunus domestica subsp. Syriaca & 1 & 7 & 11 \\
\hline 35 & Sorbus aucuparia & 1 & 7 & 13 \\
\hline 36 & Viola sp. & 1 & 7 & 14 \\
\hline 37 & Primula sp. & 1 & 7 & 15 \\
\hline 38 & Agaricus sp. & 1 & 7 & 7 \\
\hline 39 & Sparassis sp. & 1 & 7 & 13 \\
\hline
\end{tabular}

${ }^{*}$ Coding of variables: Frequency: number of respondents listing the item; Percentage: percentage of respondents listing the item; Average Rank: average rank of the item in individual freelists; 
Table 2: Gathering and preparation of the 24 most frequently listed wild food species*

\begin{tabular}{|c|c|c|c|c|c|c|c|c|}
\hline Species & Local names & Gathered part & Preparation & Freq of gathering & Cult & Habitat & Distance & Season \\
\hline Cantharellus cibarius & Eierschwammerl, Recherl & fungus & egg, gul, sce, sou, ric & $\mathrm{gFF}$ & w & woo & $\mathrm{gCC}, \mathrm{gC}$ & spr, sum \\
\hline Boletus edulis & Steinpilz, Herrenpilz & fungus & sou, sce, egg, gul, ric, bre & $\mathrm{gFF}$ & w & woo & $g C C, g C, g A$ & sum \\
\hline Rubus subgenus Rubus spp. & Brombeer & fruit & raw, mar, mil & $\mathrm{gF}$ & $c$ & woo, mea, edgwoo & $\mathrm{gCC}, \mathrm{gC}$ & sum, fall \\
\hline Macrolepiota procera & Parasol & fungus & bre, fri & gFF & w & woo & $\mathrm{gCC}, \mathrm{gC}$ & sum \\
\hline Fragaria vesca & Walderdbeer & fruit & raw, mar, mil & $\mathrm{gF}$ & w & woo, mea, edgwoo & $\mathrm{gCC}, \mathrm{gC}$ & spr, sum \\
\hline Russula sp. & Täubling & fungus & fri & $\mathrm{gF}$ & w & woo & $\mathrm{gCC}, \mathrm{gC}$ & sum \\
\hline Rubusidaeus & Himbeer & fruit & raw, mar, mil & $\mathrm{gF}$ & c & woo, mea, edgwoo & $g C C, g C, g A$ & sum, fall \\
\hline Urtica dioica & Brennnessel & leaf & spn, sal, sou & $\mathrm{gF}$ & w & mea & $\mathrm{gCC}$ & spr, sum,fall \\
\hline Taraxacum sp. & Löwenzahn & leaf & sal & $\mathrm{gF}$ & w & mea & $\mathrm{gCC}$ & spr \\
\hline Vaccinium myrtillus & Schwarzbeer, Heidelbeer & fruit & raw, mar, swe & $\mathrm{gF}$ & $C$ & woo, edgwoo & $\mathrm{gCC}, \mathrm{gA}$ & sum, fall \\
\hline Castanea sativa & Kastanie, Maroni & fruit & fri, coo, swe & $\mathrm{gF}$ & c & woo, edgwoo & $\mathrm{gCC}, \mathrm{gC}$ & fall \\
\hline Taraxacum sp. & Löwenzahn & flower & hon & gRA & w & mea & $\mathrm{gCC}$ & spr, sum \\
\hline Bellis perennis & Gänseblümchen & leaf, flower & sal & gRA & w & mea & $\mathrm{gCC}$ & spr, sum \\
\hline Lactarius sect. Deliciosi & Milchling & fungus & fri & gRA & w & woo & $\mathrm{gCC}$ & sum \\
\hline Sambucus nigra & Holunder, Holler & flower & bak & gRA & C & woo, mea, edgwoo & $g C C, g C$ & spr, sum \\
\hline Sambucus nigra & Holunder, Holler & fructus & hko & gRA & w & mea, edgwoo & $\mathrm{gCC}, \mathrm{gC}$ & sum, fall \\
\hline Juglans regia & Walnuss, Nuss & fructus & raw & gRA & c & mea & $\mathrm{gCC}, \mathrm{gC}$ & sum, fall \\
\hline Plantago lanceolata & Spitzwegerich & leaf & sou & gRA & w & mea & $\mathrm{gCC}$ & spr, sum \\
\hline Rumex sp. & Sauerampfer & leaf & sal, sou & gRA & w & mea & $\mathrm{gCC}$ & spr \\
\hline Thymus sp. & Quendel & flower, leaf & con & gRA & c & mea & $\mathrm{gCC}$ & sum \\
\hline Allium ursinum & Bärlauch & leaf & sou, sce, con & gRA & $C$ & mea & $\mathrm{gCC}$ & spr \\
\hline Prunus avium subsp. avium & Vogelkirsche & fruit & raw & gRA & w & woo, mea, edgwoo & $\mathrm{gCC}, \mathrm{gC}$ & spr, sum \\
\hline Glechoma hederacea & Gundelrebe & leaf & egg, sou & gRA & w & mea & $\mathrm{gCC}$ & spr, sum,fall \\
\hline Amanita rubescens & Perlpilz & fungus & bre, sce & gRA & w & woo & $\mathrm{gC}$ & sum \\
\hline
\end{tabular}

${ }^{*} \mathrm{n}=15$ for the variables: Gathered part, Preparation; $\mathrm{n}=10$ for the variables: Freq of gathering, Cultivation, Habitat, Distance, Season; Coding of variables: Preparation: ways of preparation or use: sou = soup, sce = sauce, con = condiment, bre = breaded, fri = fried, sal = salad, raw = raw, egg = with eggs, ric = with rice, mil = with milk (products), mar = marmalade, coo: cooked, spi: spinach hon: löwenzahnhonig, bak: gebackene hollerblüten, hko: hollerkoch; Freq of gathering: frequency of gathering: plant species gathered by gRA $=<33 \%$, gF $=33 \%-66 \%, \mathrm{gFF}=>66 \%$ each of all informants; Cult: cultivation of plants: $C=$ also cultivated, $W=$ gathered from wild only; Habitat: woo = wood, mea = meadow, edgwoo = edge of the wood; Distance: distance from farm: plant species gathered in $\mathrm{gCC}=<0,2$ kilometers, $\mathrm{gC}=0,2-5$ kilometers, $\mathrm{gA}=>5$ kilometers distance; Season: time of the year: spr $=$ spring, sum $=$ summer, fall $=$ fall; 
Rosaceae (6 species), followed by Brassicaceae and Asteraceae (3 species each), then Lamiaceae, Plantaginaceae, Boletaceae, Agaricaceae, Russulaceae and Ramariaceae (2 species each). For 15 families only one species was listed.

The wild foods are gathered from herbaceous plants (18 species), followed by mushrooms (11 species), trees and shrubs (5 species each). The items frequently gathered include: leaves (12 species), fruits and the mushroom bodies ( 11 species each) and flowers (6 species) (Table 2 ). Additionally for Urtica dioica the seeds and shoots as well as the root in the case of horseradish (Armoracia rusticana) are gathered.

Due to the very distinctive use of the flowers and the berries of elderberry (Sambucus nigra) and the flowers and the leaves of Taraxacum sp., these different plant organs are considered as different wild food plants in the following analysis.

\section{Gathering of the $\mathbf{2 4}$ most common wild food species}

The wild food species are generally gathered in close proximity to the farms of the respondents. Especially for the herbaceous plants - Taraxacum sp., Urtica dioica, perennial daisy (Bellis perennis), ribwort (Plantago lanceolata), sorrel (Rumex sp.), thyme (Thymus sp.), wild garlic (Allium ursinum) and ground ivy (Glechoma hederacea) respondents indicated that they never go further than 200 meters away to gather these plants (in total 98/145 mentions for the category "less than 200 meters"). All other plants and mushrooms (except blusher mushroom (Amanita rubescens)) are gathered within 200 meters as well, but at times the respondents may travel up to 5 kilometers from their farms to harvest them (42/145 mentions for the category "200 meters to 5 kilometers"). It's rare that respondents gather species from a far distance away from the farm, and only Vaccinium myrtillus, Rubus idaeus and Boletus edulis were gathered further away than 5 kilometers in 2007/08 (5/145 mentions for the category "more than 5 kilometers") (Table 2).
The wild food species are mainly gathered from meadows (58/123 mentions for "meadows") and all species except the mushrooms and Vaccinium myrtillus come from meadows. The mushrooms are gathered from the forest and so are the fruits from all the various shrubs (42/123 mentions for "forest"). A number of foods are also gathered at the edge of forests: fruits from all shrubs, Fragaria vesca, wild cherry (Prunus avium subsp. avium), sweet chestnut (Castanea sativa) as well as Cantharellus cibarius (25/123 mentions for "edge of the forest") (Table 2).

Most of the wild foods are gathered in summer (73/135 mentions for "summer harvesting"). All herbaceous plants and Sambucus nigra flowers are also gathered in spring (37/135 mentions for "spring harvesting"). Castanea sativa and walnuts (Juglans regia) are gathered in fall as are the fruits from all shrubs (25/135 mentions for "fall harvesting") (Table 2).

The respondents also cultivate several of the plants from which they gather edible parts in the wild. These plants include: all the listed shrubs, namely Rubus subgenus Rubus spp. (6 respondents gather this plant from the wild/7 from cultivation), Vaccinium myrtillus (2/5), Rubus idaeus (5/7), Sambucus nigra flowers (8/1); the trees Juglans regia (2/9) and Castanea sativa (6/4); and the herbaceous plants Allium ursinum (1/2) and Thymus $s p$. (1/1) (Table 2). The other 16 wild food species, which were listed at least twice in the freelists, are gathered only from the wild.

\section{Culinary use value and preparation of the $\mathbf{2 4}$ most common wild food species}

Wild food species in the hill country east of Graz are most often boiled, fried and eaten raw. Mushrooms have the highest culinary use value (CUV), followed by fruits, leaves and flowers. Mushrooms are mainly fried and boiled. Fruits are eaten raw, boiled and sometimes roasted or used in cakes. The leaves are eaten raw, boiled and fried. The flowers are eaten raw and fried (Table 3).

Table 3: Culinary use value by gathered part and preparation category $(n=15)$ *

\begin{tabular}{|c|c|c|c|c|c|c|c|}
\hline Gathered part & CUV & Boiled & Fried & Raw & Roasted/Baked & Dried/Condiment & Others \\
\hline Mushroom & 6,73 & 2,40 & 4,00 & 0,00 & 0,00 & 0,20 & 0,13 \\
\hline Fruit & 6,47 & 2,47 & 0,00 & 3,20 & 0,80 & 0,00 & 0,00 \\
\hline Leaf & 2,67 & 0,67 & 0,60 & 0,93 & 0,00 & 0,20 & 0,27 \\
\hline Flower & 0,53 & 0,00 & 0,20 & 0,33 & 0,00 & 0,00 & 0,00 \\
\hline Total & & 5,53 & 4,80 & 4,47 & 0,80 & 0,40 & 0,40 \\
\hline
\end{tabular}

*Coding of variables: CUV: Culinary use value; Boiled: cooked, prepared as a soup, gulasch, rice, marmalade, compote; Fried: fried in oil, prepared as a spinach, as a sauce, with eggs or breadened and fried; Raw: eaten raw, prepared as a salad, mixed with milk (products) or sugar, macerated in sugar; Roasted/baked: roasted or baked in oven, tarts and cakes; Dried/condiment: used as a condiment, most often dried first; Others: used in spreads, laibchen, on pizza or for garnishing; 
Table 4: Culinary use value by species and preparation category including total number of uses and different uses ( $n=15$ )

\begin{tabular}{|c|c|c|c|c|c|c|c|c|c|c|}
\hline Species - Latin names & Species - English names & CUV & Boiled & Fried & Raw & Roasted/baked & Dried/condiment & Others & Uses & Different uses \\
\hline Boletus edulis & boletus mushroom & 2,47 & 1,13 & 1,07 & 0 & 0 & 0,20 & 0,07 & 37 & 8 \\
\hline Cantharellus cibarius & chanterelle mushroom & 2,33 & 1,20 & 1,07 & 0 & 0 & 0 & 0,07 & 35 & 8 \\
\hline Rubus subgenus Rubus spp. & blackberry & 1,47 & 0,73 & 0 & 0,73 & 0 & 0 & 0 & 22 & 7 \\
\hline Rubusidaeus & raspberry & 1,20 & 0,53 & 0 & 0,67 & 0 & 0 & 0 & 18 & 7 \\
\hline Fragaria vesca & wood strawberry & 1,20 & 0,40 & 0 & 0,80 & 0 & 0 & 0 & 18 & 5 \\
\hline Vaccinium myrtillus & blueberry & 1,07 & 0,33 & 0 & 0,60 & 0,13 & 0 & 0 & 16 & 9 \\
\hline Urtica dioica & nettle & 0,93 & 0,20 & 0,47 & 0,20 & 0 & 0 & 0,07 & 14 & 5 \\
\hline Macrolepiota procera & parasol mushroom & 0,87 & 0 & 0,87 & 0 & 0 & 0 & 0 & 13 & 2 \\
\hline Castanea sativa & sweet chestnut & 0,87 & 0,27 & 0 & 0 & 0,60 & 0 & 0 & 13 & 5 \\
\hline Russula sp. & flirt mushroom & 0,67 & 0,07 & 0,60 & 0 & 0 & 0 & 0 & 10 & 2 \\
\hline Taraxacum sp. leaves & dandelion leaves & 0,53 & 0,07 & 0 & 0,47 & 0 & 0 & 0 & 8 & 2 \\
\hline Allium ursinum & wild garlic & 0,33 & 0,07 & 0,07 & 0 & 0 & 0,07 & 0,13 & 5 & 5 \\
\hline Taraxacum sp. flowers & Dandelion flowers & 0,33 & 0 & 0 & 0,33 & 0 & 0 & 0 & 5 & 1 \\
\hline Bellis perennis & perennial daisy & 0,33 & 0,07 & 0 & 0,20 & 0 & 0 & 0,07 & 5 & 4 \\
\hline Sambucus nigra fruits & elderberry fruits & 0,27 & 0,20 & 0 & 0,07 & 0 & 0 & 0 & 4 & 2 \\
\hline Lactarius sect. Deliciosi & lactarius mushroom & 0,27 & 0 & 0,27 & 0 & 0 & 0 & 0 & 4 & 1 \\
\hline Juglans regia & walnut & 0,27 & 0 & 0 & 0,20 & 0,07 & 0 & 0 & 4 & 2 \\
\hline Sambucus nigra flowers & elderberry flowers & 0,20 & 0 & 0,20 & 0 & 0 & 0 & 0 & 3 & 1 \\
\hline Glechoma hederacea & ground ivy & 0,13 & 0,07 & 0,07 & 0 & 0 & 0 & 0 & 2 & 2 \\
\hline Amanita rubescens & blusher mushroom & 0,13 & 0 & 0,13 & 0 & 0 & 0 & 0 & 2 & 2 \\
\hline Thymus sp. & thyme & 0,13 & 0 & 0 & 0 & 0 & 0,13 & 0 & 2 & 1 \\
\hline Rumex sp. & sorrel & 0,13 & 0,07 & 0 & 0,07 & 0 & 0 & 0 & 2 & 2 \\
\hline Plantago lanceolata & ribwort & 0,13 & 0,13 & 0 & 0 & 0 & 0 & 0 & 2 & 1 \\
\hline Prunus avium subsp. avium & wild cherry & 0,13 & 0 & 0 & 0,13 & 0 & 0 & 0 & 2 & 1 \\
\hline Total & & & 5,53 & 4,80 & 4,47 & 0,80 & 0,40 & 0,40 & 246 & 85 \\
\hline
\end{tabular}


The species with the highest CUV are Boletus edulis and Cantharellus cibarius. The most common way of preparation is boiling, followed by frying. Boletus is also sometimes dried (Table 4). These two mushroom species are eaten in diverse ways, namely in soups, as a sauce, fried with eggs, as a gulasch and with rice (Table 2). The other mushroom species have lower CUVs. Macrolepiota procera is mainly eaten breaded and fried. Russula sp., Lactarius sect. Deliciosi and Amanita rubescens are mainly fried.

The fruits of Rubus subgenus Rubus spp., Rubus idaeus, Fragaria vesca and Vaccinium myrtillus have high CUVs. They are eaten raw, mixed with milk or milk products (like yoghurt or curd) or processed into jam.

Urtica dioica and Taraxacum sp. leaves are the leafy wild food plants with the highest CUVs. Urtica dioica is fried (often prepared as spinach), boiled or eaten raw, while Taraxacum sp. leaves are almost only eaten raw (often mixed with potatoes in a salad called Röhrlsalat). The other herbaceous plant species are mainly eaten in salads (Bellis perennis, Rumex sp.) and soups (Plantago lanceolata, Rumex sp., Allium ursinum, Glechoma hederacea).

For some plants very special ways of preparation were reported. The flowers of Sambucus nigra are dipped in batter and then fried (Gebackene Hollerblüten). The flowers of Taraxacum $s p$. are cooked or macerated in sugar to produce syrup (Löwenzahnhonig), which is used like a honey. The fruits of Sambucus nigra are processed with apples (Malus domestica), prunes (Prunus domestica subsp. domestica) and sugar to make a kind of jam ( Holunderkoch).

The highest number of uses was listed for Boletus edulis (total of 37 uses including double mentions), Cantharellus cibarius (35 uses) and Rubus subgenus Rubus spp. (22 uses). The highest number of different uses was listed for Vaccinium myrtillus (nine different uses), Boletus edulis and Cantharellus cibarius (eight different uses each) (Table 4).

\section{Classification of the $\mathbf{2 4}$ most commonly used wild food species}

The classification of wild food species following HCA reveals four distinct clusters. These clusters consist of two times five, six and eight plants or mushrooms (Table 5, Figure 1).

The HCA of gather and use variables also yields four clusters (Figure 2). The variables in the first cluster (CoV1) are: "gathering of mushrooms", "very frequent listing" and "very frequent gathering" and the preparation of plants or mushrooms "with eggs", "with rice", "as a sauce", "fried" or "breaded". This cluster of variables matches with the CoP-C, containing all mushrooms. The CoP-C is divided into two subclusters at level 8 . This division can be explained through the distinct ways of preparation since Macrolepiota procera, Russula sp., Lactarius sect. Deliciosi and Amanita rubescens are consumed mainly fried or breaded and Cantharellus cibarius and Boletus edulis are rather prepared with eggs, with rice or as a sauce. The items of this cluster are labeled by the local term "schwammerl".

The second cluster of variables $(\mathrm{CoV}-2)$ consists of the variables: "use of the flowers", "use as a condiment", "use of the leaves", "preparation as a salad", "preparation as a soup", the "rare listing" and "rare gathering of the plant or mushroom", "gathering from meadows" and "gathering in spring". CoP-A matches with this cluster of variables. CoP-A is divided in two subclusters at level 6 . This division can be explained since Urtica dioica and the leaves of Taraxacum sp. are gathered very frequently and not rarely like the other plants in this cluster. A further subcluster in the CoP-A occurs at level 3 and comprises Allium ursinum and Thymus sp., which, in contrast to the other plants, also used as a condiment. The plants in this cluster are locally labeled "kräuter".

The third cluster of variables $(\mathrm{CoV}-3)$ incorporated the variables: "raw consumption", "consumption with milk or milk products", "consumption as jam", "gathering far away from the farm", "listed and gathered frequently", "gathering of fruits", "gathering from the edge of the forest", "gathering from cultivated plants as well" and "gathering in fall". This cluster matches with the CoP-D. Within the CoP-D, Castanea sativa represents a subcluster as this food is mainly roasted or cooked whereas the other plant foods are consumed raw or with milk or milk products. The items of this cluster (except Castanea sativa) are locally labeled "beeren".

The fourth cluster of variables $(\mathrm{CoV}-4)$ consists of the variables: "gathering in the forest", "gathering very close to the farm", "gathering close to the farm" and "gathering during summer". These four variables often occur together; however they are valid for multiple plants of several clusters. They cannot be clearly attributed to one cluster of plants and therefore comprise this distinct cluster.

The B cluster of plants (CoP-B) does not match very well with any of the clusters of variables. The plants in this cluster are gathered in meadows and are rarely gathered, which are variables of the $\mathrm{CoV}-2$, but, contrary to $\mathrm{CoV}-2$, they are not prepared in salads or soups but often in very unique ways. Also the fruits and flowers are gathered rather than the leaves. In the CoP-B the flowers of Sambucus nigra and the flowers of Taraxacum sp. set up a subcluster at level 5 since the flowers from both plants are gathered and in both cases they are prepared in unique ways (baked and as a "honey"). Due to the inconsistent composition of this cluster there is no local generic term that applies to it. 
Table 5: Description of cluster of species elicited through hierarchical cluster analysis $(n=10)$

\begin{tabular}{|c|c|c|c|c|c|c|c|}
\hline Cluster & $\begin{array}{l}\text { Number of } \\
\text { items }\end{array}$ & $\begin{array}{l}\text { Overall } \\
\text { Frequency }\end{array}$ & $\begin{array}{l}\text { Std.Dev. (overall } \\
\text { frequency) }\end{array}$ & Frequent Taxa & Label & Typical preparations & Description \\
\hline COP-A & 8 & 4.6 & 3.4 & $\begin{array}{l}\text { Taraxacum sp.leaves; } \\
\text { Urtica dioica }\end{array}$ & kräuter & $\begin{array}{l}\text { Löwenzahnsalat (Röhrlsalat); } \\
\text { Brennnesselspinat; }\end{array}$ & $\begin{array}{l}\text { Flowers and leaves, rarely listed and rarely gathered, used } \\
\text { as condiment, in soups or salads, gathered in spring }\end{array}$ \\
\hline COP-B & 5 & 5 & 2 & $\begin{array}{l}\text { Taraxacum sp. flowers; } \\
\text { Sambucus nigra fruits } \\
\text { and flowers }\end{array}$ & no label & $\begin{array}{l}\text { Löwenzahnhonig; Gebackene } \\
\text { Holunderblüten; } \\
\text { Holunderkoch; }\end{array}$ & $\begin{array}{l}\text { Fruits and flowers, gathered rarely, often used in unique } \\
\text { preparations }\end{array}$ \\
\hline CoP-C & 6 & 8.3 & 4.3 & $\begin{array}{l}\text { Cantharellus cibarius; } \\
\text { Boletus edulis; }\end{array}$ & schwammerl & $\begin{array}{l}\text { Schwammerlsuppe; } \\
\text { Schwammersauce; } \\
\text { Schwammerlgulasch; }\end{array}$ & $\begin{array}{l}\text { Mushrooms, very frequently listed and gathered, } \\
\text { prepared with eggs, with rice, fried, as a sauce or breaded }\end{array}$ \\
\hline COP-D & 5 & 8.8 & 2.4 & $\begin{array}{l}\text { Rubus subgenus Rubus } \\
\text { spp.; Fragaria vesca; } \\
\text { Rubus idaeus; }\end{array}$ & beeren & $\begin{array}{l}\text { Raw;Marmalade; Fruchtmilch; } \\
\text { Fruchtjoghurt; }\end{array}$ & $\begin{array}{l}\text { Fruits, frequently listed and gathered, consumed raw, as } \\
\text { jam or with milk (products), gathered from cultivated } \\
\text { plants as well; }\end{array}$ \\
\hline
\end{tabular}




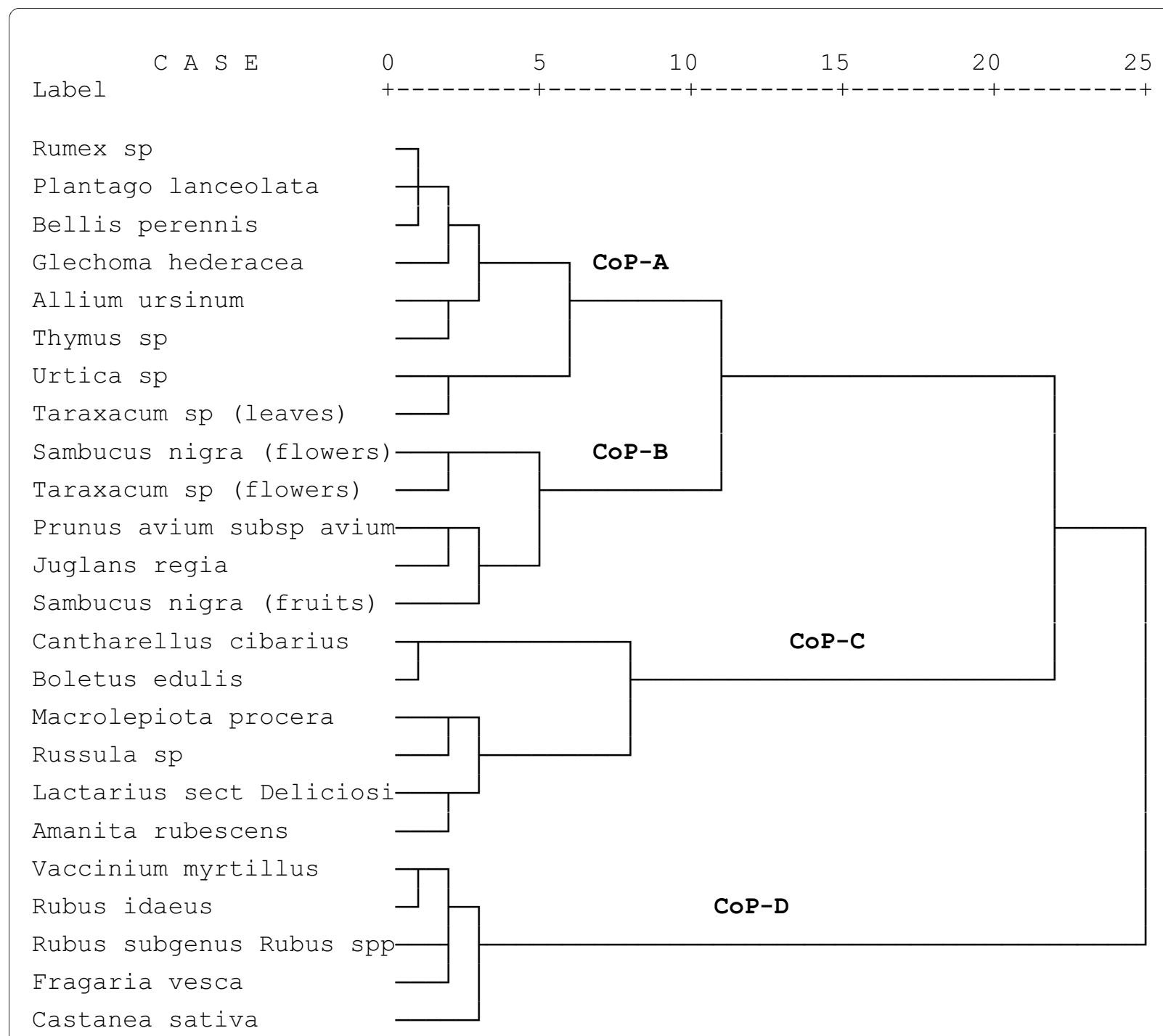

Figure 1 Dendrogram of wild food species created through Hierarchical Cluster Analysis of gather and use variables $(n=10)$.

\section{Discussion}

\section{Plant and mushroom species/habit/families}

Among the eight most frequently listed plant and mushroom species, mushroom bodies (4 species) are gathered most often, then fruits (3 species) and leaves (1 species). Among the 14 most frequently listed species, fruits are listed most often ( 6 species), followed by mushroom bodies (4 species), leaves ( 2 species) and flowers ( 2 species). Following our study the gathering of mushrooms and fruits for food is therefore most common among farmers in the hill country east of Graz. However, our data is potentially biased since we collected data only during summer and autumn and not during spring, when most of the leafy vegetables and flowers are gathered.

The commonly gathered mushrooms and fruits are recorded as wild food species in many other areas as well
$[14,17,42-45]$. Uses of leaves and flowers are known to only a few respondents. Urtica dioica and Taraxacum sp. leaves are the exceptions. Similar results were found in Poland, where the gathering of 15 species of fruits and only 2 of leafy vegetables is reported as common [14]. In other regions such as Spain [45], Bosnia-Herzegovina [17] or Italy [46] leafy vegetables were found as frequently gathered.

The best known and several of the less known edible mushroom species gathered in Styria today were in use at the beginning of the $20^{\text {th }}$ century already (Boletus edulis, Cantharellus cibarius, Macrolepiota procera, Russula sp., Lactarius sect. Deliciosi, Agaricus sp., Sparassis sp.) $[21,23]$. The use of Taraxacum $s p$. as salad, Glechoma hederacea in omelets and of Urtica sp., Achillea sp. and Nasturtium sp. was also found in historic literature as 
well as in this study. However, the gathering of the mushrooms Clavaria aurea, Tricholoma sp., Polyporus squamosus, Clitopilus prunulus and the leafy vegetables Cichorium sp., Hieracium sp. and Crocus vernus was only encountered in historic literature [21].

The most important family in terms of wild food plants and mushrooms is Rosaceae. This is identical to findings in Poland [14] and similar to the Mediterranean area [47], where only species in Asteraceae are more important. Plants of Asteraceae have several, although rarely listed uses in the hill country east of Graz (one exception is the frequent use of Taraxacum $s p$. leaves for salad). This is similar to findings in Poland, where Asteraceae is the best represented family for green vegetables, although most of the uses are obsolete today. No plants of Liliaceae and Apiaceae were listed as gathered in the hill country east of Graz, although they are important wild food plant families in the Mediterranean area [47].

The field of ethnomycology is much younger than the field of ethnobotany [48] and wild gathered mushrooms are often neglected in ethnobiological studies still today [1]. However, the few ethnobiological studies which considered wild edible mushrooms in Europe found a diversity of gathered wild mushroom species. In Sicily 78 mushroom species are reported to be gathered and consumed [49] and in the southern Italian village of Castelmezzano 13 wild gathered mushroom species were registered [1]. In the hill country the gathering of wild edible mushrooms is also very common and some of the most salient wild food items are mushrooms. Eleven wild gathered mushroom species were recorded in this study. The use of Boletus edulis, Cantharellus cibarius, Macrolepiota procera, Russula sp. and Lactarius sect. Deliciosi is widespread and documented in many other areas as well $[42,43,49]$.

\section{Culinary preparations}

The gathered fruits in the Mediterranean are mainly consumed raw, as a jam or dried [47]. While eating fruits raw or as a jam is common in the hill country as well, the drying of fruits was not reported. Conversely the mixing of wild gathered fruits with milk or milk products, common in the hill country, was rarely found in other studies. However the mixing of Vaccinium myrtillus with milk or cream was documented for Poland [14].

Gathered greens in the Mediterranean are most often boiled and fried, stewed, eaten raw, and used in salads, omelets or pies $[45,47]$. In the hill country the boiling, frying and raw consumption of gathered leaves are known as well, whereas the preparation of omelets or pies with wild gathered leaves is almost absent. Only Glechoma hederacea was listed once to be used in omelets. The most widespread uses of gathered greens are for Taraxacum $s p$. leaves as a salad, often mixed with potatoes (Solanum tuberosum) (Röhrlsalat), and the preparation of Urtica dioica as a spinach.

The wild gathered mushrooms are most often roasted, stewed or eaten raw in southern Italy and Sicily $[1,49]$, whereas in the hill country mushrooms are boiled or fried.

\section{Classification}

In the hill country four different clusters of plant and mushroom species were found, as compared to CastillaLa Mancha, where eight clusters were elicited [9]. Three clusters are similar between the regions. In both areas leaves, used in soups and salads, mushrooms, which are fried, and fruits, used for making jam, are gathered.

Two different types of clusters, species labeled and use labeled ones, can occur, when plants or mushrooms are classified through usage patterns [9]. Species labeled clusters include label species, hence species which are used frequently by the informants, as well as rarely used species. The label species are widely known and used extensively while the other species in the cluster are often used as their substitutes. The standard deviation is high in species labeled clusters. In contrast, use labeled clusters do not have label species and a lower standard deviation [9]. In both kinds of clusters plant species are assembled because they are gathered and used in similar ways.

Following this concept, CoP-A and CoP-C are species labeled. Both clusters have label species (CoP-A: Taraxacum sp. leaves and Urtica dioica; CoP-C: Cantharellus cibarius and Boletus edulis), high standard deviation and several species that might substitute for the label species. Hence, for leaves and mushrooms the label species are used frequently, while the use of other species is less widespread. CoP-B and CoP-D are use labeled, since no label species occur and the standard deviation is low for both clusters (fruits and flowers in CoP-B are all rarely listed and the fruits in CoP-D are all frequently listed). Thus the species within these two clusters are used similarly often, and no outstanding, typical species can be named.

The classification following usage patterns does not follow the species concept and species boundaries and morphology of species are neglected [9]. This is true for CoP$\mathrm{B}$ and CoP-D, where herbaceous plants, shrubs and trees are assembled in one cluster.

The clustering of wild food species following usage patterns represents a new way for discovering how people structure and manage their environment and cluster analysis helps to understand which species are selected from an environment and which are omitted [9]. However, it should be considered that the choice of variables used in cluster analysis may heavily influence the results. In this study eleven out of 31 variables were related to food preparation. Thus, special weight was given to food 
preparation and a different choice of variables might have yielded different results. Furthermore, it should be considered that this kind of classification is not fully emic, since researchers rather than the respondents select the variables to be used in the analyses.

\section{Conclusions}

The gathering and use of several wild food species is common among farmers in the hill country east of Graz. Fruits and mushrooms in particular are gathered frequently. Wild leafy vegetables are gathered rarely, although a diversity of wild leafy food plants was documented. The plant and mushroom species gathered in the hill country are often the same as those gathered in other European regions. However, some uncommon preparations were found in the study area.

In past research culinary preparations of wild food species were presented most often without indicating the relative importance of the preparations (e.g. $[1,9,11,49]$ ). Sometimes the percentage of plant species prepared in special ways (e.g. [17]) or the frequency of citation of distinct uses is considered (e.g. [45]). However, a quantitative index indicating the culinary importance has been lacking. The culinary use value (CUV), as applied in this study, attributes culinary importance indices to both, distinct species and distinct ways of preparation. This facilitates the evaluation of the culinary importance of species and of the significance of distinct ways of preparation in the research area. Furthermore, this index makes the comparison of the relative importance of species and preparations between different regions, as well as over time, possible.

The concept of "specialized" use value (such as "culinary" use value) could be applied in other fields of study as well (e.g. as a "medicinal use value" for medicinally used plant species, or "ornamental use value" for plant species used for ornamental purposes). This further development of indices adds to quantification in ethnobotany.

The classification of wild food species through gathering and use variables reveals additional information about which wild food species are used in an area and about differences in preparation. This classification can be used to better understand how people classify their environment and how they select certain wild food species and neglect others. However, attention should be given to the selection of variables. In the hill country the classification shows that fungi, prepared in diverse ways, flowers and leaves used as spices, in soups or salads, and fruits, eaten raw, with milk (products) or as jam are the prevalent clusters of wild food uses.

This study found that local knowledge about wild food species and their uses is still existent among farmers in the hill country east of Graz. However, it can be supposed that important amounts of wild food knowledge got lost over the course of the $19^{\text {th }}$ and $20^{\text {th }}$ century through fundamental changes in the way of living in rural areas, which occurred everywhere in Europe [1,14,40]. The documentation of local knowledge is just a first step in order to reduce the loss of local knowledge. For its long-term survival, in-situ conservation, hence conservation by local people in place is essential [50]. Strategies for the local dissemination of local knowledge may include books, expositions, gardens and learning materials for schools [4]. Furthermore, organisations like Slow Food [26], which work in the area of food heritage and conservation of endangered food, can contribute to the revival of wild food uses [40]. This may result in an increasing demand for wild food species and finally will offer marketing possibilities for organic farmers, the informants of this study.

\section{Competing interests}

The authors declare that they have no competing interests.

\section{Authors' contributions}

CS carried out the study design, field research, analysis of data and writing of the paper. CRV substantially assisted in all stages of the study. Both authors read and approved the final manuscript.

\section{Acknowledgements}

We thank all farmers who welcomed us and kindly shared their knowledge and time and the LEADER-manager Heinrich-Maria Rabl for providing contact in the research area. We are grateful to the anonymous reviewers, who made valuable contributions to improve this paper.

\section{Author Details}

Working Group: Knowledge Systems and Innovations, Division of Organic Farming, Department for Sustainable Agricultural Systems, University of Natural Resources and Applied Life Sciences (BOKU), Gregor-Mendel Straße 33, 1180 Vienna, Austria

Received: 19 February 2010 Accepted: 21 June 2010 Published: 21 June 2010

\section{References}

1. Pieroni A, Nebel S, Santoro RF, Heinrich M: Food for two seasons: Culinary uses of non-cultivated local vegetables and mushrooms in a south Italian village. International Journal of Food Sciences and Nutrition 2005, 56:245-272.

2. Pardo-de-Santayana M, Tardío J, Morales R: The gathering and consumption of wild edible plants in the Campoo (Cantabria, Spain). International Journal of Food Sciences and Nutrition 2005, 56:529-542.

3. Heinrich M, Leonti M, Nebel S, Peschel W: "Local food - nutraceuticals": an example of a multidisciplinary research project on local knowledge. Journal of Physiology and Pharmacology 2005, 56:5-22.

4. Heinrich M, Nebel S, Leonti M, Rivera D, Obón C: Local FoodNutraceuticals': Bridging the gap between local knowledge and global needs. In Local Mediterranean Food Plants and Nutraceuticals Edited by: Heinrich M, Müller WE, Galli C. Basel: Karger; 2006:1-17.

5. Pieroni A, Quave CL: Eating and Healing: Traditional food as medicine. In Eating and Healing: Traditional food as medicine Edited by: Pieroni A and Price LL. Binghamton NY: The Haworth Press; 2006:101-129.

6. Fischer M: Wilde Genüsse: eine Enzyklopädie der essbaren Wildpflanzen von Adlerfarn bis Zirbelnuss. Wien: Mandelbaum Verlag; 2007.

7. Machatschek M: Nahrhafte Landschaft: Ampfer,Kümmel, Wildspargel, Rapunzelgemüse, Speiselaub und andere wiederentdeckte Nutz- und Heilpflanzen. Böhlau Verlag; 1999. Wien, Köln, Weimar 
8. Rivera D, Obón C, Heinrich M, Inocencio C, Verde A, Fajardo J: Gathered mediterranean food plants: ethnobotanical investigations and historical development. In Local Mediterranean Food Plants and Nutraceuticals Edited by: Heinrich M, Müller WE, Galli C. Basel: Karger: 2006:18-74.

9. Rivera D, Obón C, Inocencio C, Heinrich M, Verde A, Fajardo J, Palazón J: Gathered food plants in the mountains of Castilla-La Mancha (Spain): Ethnobotany and multivariate analysis. Economic Botany 2007, 61:269-289.

10. Tardío J, Pascual H, Morales R: Wild food plants traditionally used in the province of Madrid Central Spain. Economic Botany 2005, 59:122-136.

11. Bonet MÀ, Vallès J: Use of non-crop food vascular plants in Montseny biosphere reserve (Catalonia, Iberian Peninsula). International Journal of Food Sciences and Nutrition 2002, 53:225-248.

12. Scherrer AM, Motti R, Weckerle CS: Traditional plant use in the areas of Monte Vesole and Ascea Cilento National Park (Campania, Southern Italy). Journal of Ethnopharmacology 2005, 97:129-143.

13. Nebel S, Pieroni A, Heinrich M: Ta chòrta: Wild edible greens used in the Graecanic area in Calabria Southern Italy. Appetite 2006, 47:333-342.

14. Łuczaj L, Szymański WM: Wild vascular plants gathered for consumption in the Polish countryside: a review. Journal of Ethnobiology and Ethnomedicine 2007, 3:17.

15. Ujvary Z: A vadontermö növények szerepe a tàplàlkozásban az abaújzempléni hegyvidéken. Néprajzi Értesítő 1958. Debrecen

16. Gunda B: Sammelwirtschaft bei den Ungarn. In Ungarische Jahrbücher Volume 18. Edited by: Farkas J. Berlin: Walter de Gruyter \& Co; 1938:302-317.

17. Redzic SJ: Wild Edible Plants and Their Traditional Use in the Human Nutrition in Bosnia-Herzegovina. Ecology of Food and Nutrition 2006, 45:189-232

18. Cerne M: Wild plants from Slovenia used as vegetables. Acta Horticulturae 1992:87-96.

19. Gunda B: Plant gathering in Eurasia. Southwestern Journal of Anthropology 1949, 5:369-378

20. Gamerith A: Die Nahrung des steirischen Bauern. In Der steirische BauerLeistung und Schicksal von der Steinzeit bis zur Gegenwart Edited by: Posch F. Graz: Steiermärkisches Landesarchiv; 1966:338-367.

21. Fuchs HM: Die Bauernkost im Sulmtale. In Zeitschrift für Volkskunde Volume 39. Edited by: Boehm F. Berlin und Leipzig: Walter de Gruyter \& Co; 1930:26-50.

22. Unger T, Khull F: Steirischer Wortschatz - als Ergänzung zu Schmellers Bayerischem Woerterbuch. Graz: Leuschner und Lubensky; 1903.

23. Ferk F: Volkstümliches aus dem Reich der Schwämme. In Mitteilungen des Naturwissenschaftlichen Vereines für Steiermark Graz: Verlag des Naturwiss. Vereines für Steiermark; 1910.

24. Staudinger: Sammel-Merkblatt. Beilage zum Verordnungsblatte des k.k. Landesschulrates und der k.k. Statthalterei. Edited by k.k. Landeskulturinspektorate Graz. 1916. Steiermärkisches Landesarchiv

25. Walter L: Die Reichsarbeitsgemeinschaft "Ernährung aus dem Walde". Werkblätter für Kultur Bau- und Heimatpflege im Reichsgau Steiermark. Graz; 1942. Steiermärkisches Landesarchiv

26. Slow Food International: [http://www.slowfood.com]. Last access: 01/08/ 2010

27. Hügelland östlich von Graz: [http://www.huegelland.at]. Last access: 06/ 09/2010

28. Wakonigg H, Hawranek V, Lackner F, Podesser A, Rieder H: Niederschläge. [http://www.umwelt.steiermark.at/cms/beitrag/10741599/16178332]. Last access: 01/08/2010

29. Wakonigg H, Hawranek V, Podesser A, Rieder H: Temperatur. [http:// www.umwelt.steiermark.at/cms/beitrag/10703612/16178332]. Last access: 01/08/2010

30. Straka M: Erläuterungen zum Atlas der Steiermark. Graz: Akademische Druck- u. Verlagsanstalt; 1973.

31. Kaser K, Stocker K: Bäuerliches Leben in der Oststeiermark seit 1848: Band 1, Landwirtschaft von der Selbstversorgung zum Produktivitätszwang. Wien, Köln, Graz: Böhlau Verlag; 1986.

32. Haimböck H: Agrarischer Strukturwandel im Südöstlichen Flach- und Hügelland Österreichs. Österreich in Geschichte und Literatur (mit Geographie) 1985, 29:171-199.

33. Bernard HR: Research methods in anthropology: qualitative and quantitative approaches. Walnut Creek: Altamira Press; 2002.
34. Weller SC, Romney AK: Systematic data collection. Newbury Park, London,New Delhi: Sage Publications; 1988.

35. Microsoft. In Microsoft Access 2002 Redmont: Microsoft corporation; 2001.

36. Vogl CR, Vogl-Lukasser B, Puri RK: Tools and Methods for Data Collection in Ethnobotanical Studies of Homegardens. Field Methods 2004, 16:285-306.

37. Phillips O, Gentry A: The useful plants of Tambopata Peru: I. Statistical hypotheses tests with a new quantitative technique. Economic Botany 1993, 47:15-32.

38. Tardío J, Pardo-de-Santayana M: Cultural Importance Indices: A Comparative Analysis Based on the Useful Wild Plants of Southern Cantabria (Northern Spain). Economic Botany 2008, 62:24-39.

39. Hoffman B, Gallaher T: Importance Indices in Ethnobotany. Ethnobotany Research \& Applications (2007) 2008, 5:201-218.

40. Pardo-de-Santayana M, Tardio J, Blanco E, Carvalho A, Lastra J, San Miguel E, Morales R: Traditional knowledge of wild edible plants used in the northwest of the Iberian Peninsula (Spain and Portugal): a comparative study. Journal of Ethnobiology and Ethnomedicine 2007, 3:27.

41. SPSS 15.0. für Windows Chicago: SPSS Inc; 2006.

42. De Roman M: Wild Useful Fungi - a guide to edibility. [http://www.wi Idusefulfungi.org]. Last access: 01/08/2010

43. Boa E: Wild edible fungi: a global overview of their use and importance to people. Rome: FAO; 2004.

44. Plants For A Future - edible medicinal and useful plants for a healthier world [http://www.pfaf.org]. Last access: 01/08/2010

45. Tardío J, Pardo-de-Santayana M, Morales R: Ethnobotanical review of wild edible plants in Spain. Botanical Journal of the Linnean Society 2006, 152:27-71.

46. Ghirardini MP, Carli M, del Vecchio N, Rovati A, Cova O, Valigi F, Agnetti G Macconi M, Adamo D, Traina M, Laudini F, Marcheselli I, Caruso N, Gedda T, Donati F, Marzadro A, Russi P, Spaggiari C, Bianco M, Binda R, Barattieri E, Tognacci A, Girardo M, Vaschetti L, Caprino P, Sesti E, Andreozzi G, Coletto E, Belzer G, Pieroni A: The importance of a taste - a comparative study on wild food plant consumption in twenty-one local communities in Italy. Journal of Ethnobiology and Ethnomedicine 2007, 3:22.

47. Leonti M, Nebel S, Rivera D, Heinrich M: Wild gathered food plants in the European mediterranean: A comparative analysis. Economic Botany 2006, 60:130-142

48. Moerman D: The Mushroom Issue an Introduction. Economic Botany 2008, 62:205-206.

49. Lentini F, Venza F: Wild food plants of popular use in Sicily. Journal of Ethnobiology and Ethnomedicine 2007, 3:15.

50. Zent S: Ethnoecology - knowledge resources, and rights. In Ethnoecology - knowledge resources, and rights Edited by: Gragson TL, Blount BG. Athens: University of Georgia Press; 1999:90-124.

doi: 10.1186/1746-4269-6-17

Cite this article as: Schunko and Vogl, Organic farmers use of wild food plants and fungi in a hilly area in Styria (Austria) Journal of Ethnobiology and Ethnomedicine 2010, 6:17

\section{Submit your next manuscript to BioMed Centra and take full advantage of:}

- Convenient online submission

- Thorough peer review

- No space constraints or color figure charges

- Immediate publication on acceptance

- Inclusion in PubMed, CAS, Scopus and Google Scholar

- Research which is freely available for redistribution 